\title{
Lexical and Morphological Innovations in Eghagha's Rhythms of the Last Testament - A Stylistic Inquiry
}

\author{
Macaulay Mowarin ${ }^{1}$ \\ ${ }^{1}$ Department of English and Literary Studies, Delta State University, Abraka, Nigeria \\ Correspondence: Macaulay Mowarin, Department of English and Literary Studies, Delta State University, Abraka, \\ Nigeria. E-mail: mamowarin@yahoo.co.uk
}

Received: June 8, 2013

Accepted: September 26, 2013

Online Published: November 26, 2013

doi:10.5430/elr.v2n2p66

URL: http://dx.doi.org/10.5430/elr.v2n2p66

\begin{abstract}
This paper is a stylistic analysis of how Eghagha innovatively and creatively manipulates lexical items and engages in morphological innovations in order to foreground the themes of the adverse effect of socio-economic and political misrule by Nigerian rulers on the ordinary man in the Niger Delta region in particular and Nigeria in general. It focuses on the themes of the environmental degradation in the Niger Delta region and that of hope for emancipation of ordinary Nigerians from the tyrannical and corrupt practices of Nigerian rulers. Collocational shifts, lexical paradigms, loan words, neologisms and metaphorical expressions constitute the lexical items that Eghagha creatively manipulate in Rhythms of the Last Testament. The specific morphological patterns innovatively manipulated by Eghagha are affixation and compounding. The paper concludes that Eghagha's creative manipulation of English diction and morphology foregrounds the interface between language and literary creativity in the use of the English Language.
\end{abstract}

Keywords: Lexical, Morphological, Eghagha, Neologism, Innovative, Affixation, Compounding

\section{Introduction}

The struggle of African writers for the enthronement of an egalitarian society through good leadership in African countries permeates all developing countries of the world. The focus of the writers is to expose the mediocrity, autocracy and kleptocracy of the rulers which resulted in anarchy, corruption and abject poverty of majority of Africans. The malnourished state of most Africans is at variance with the opulent and avaricious lifestyle of the rulers and their cronies.

The decision of African poets in neo-colonial Africa to use verbal weapons as a medium of engagement in order to expose and to draw world attention to the problem of political mal-administration has resulted in the politician and the poet to always be at loggerheads. Munene, M (2006:187) aptly describes the frosty relationship between the two professions thus: "politics and intellectualism are constant partners that are often antagonistic and sometimes friendly.

Nigerian, as well as African poets, are engines of socio-political and economic change because they try to reflect what Awhefeada (2006:370) calls "the reality of time and place in denouncing the negative consequences of these realities". Eghagha's collection of poems titled Rhythms of The Last Testament is at the conceptual centre of the interface between poetry and history since it embodies a fictionalization of Nigeria's historical records within the past three decades. In an attempt to respond to the socio-political and economic degeneration of his country in the recent past, Eghagha reshuffles and subjects the historical facts to vivisection. This is the hallmark of commitment in African literature as Nazareth (1965:6) observes thus:

I would say that no African who writes about society in present day Africa cannot avoid being committed and political - in the sense that every attempt to re-organize society in Africa is a move which affects everybody, the figures at the top and the bottom

The paper is a literary stylistic analysis of how Eghagha manipulates words and creatively engages in morphological innovations to foreground three themes of environmental degradation in the Niger Delta region; the abject poverty and disease ravaging the land in conjunction with the torture, incarceration, and murder of political and environmental activists by tyrannical and avaricious rulers. Finally is the theme of hope for the emancipation of Nigerians from the tyrannical rulers that Eghagha calls (2002:iii) "the apes in power. 


\section{Stylistics}

Stylistics is a discipline in Linguistics which studies style. Different stylistic approaches have evolved due to the influences of linguistics and literary criticism. Subtypes of stylistics that have evolved within the past five decades include: linguistic stylistics, socio-stylistics, computational stylistics, critical stylistics and literary stylistics (See Wales, 1980; Halliday, 1973a). This study is literary stylistics. Ayeomoni (2009:5) observes that:

literary stylistics spans the border of the two subjects, linguistics and literature or literary criticism. It also deals with relating linguistic features to context in order to make the meaning as explicit as possible. The linguistic structure of a text is analysed ... in order to understand the structure of a text and the relation between them and the meanings.

Unlike a literary study of a text, a literary stylistic study is objective in the sense that the evaluations of a text are not made until all the linguistic features have been studied, evaluated and interpreted. A literary stylistic study does not accommodate either metaphysical or extra-textual reference while the evaluation of a text is being made. Banjo (1982:6) stresses that an ideal stylistic analysis:

should proceed from analysis to synthesis and then to the effectiveness of the use of language in the text to an examination of the way in which linguistic devices are used to build up and reference the meaning of the text.

Such an examination invariably ends with an evaluation on whether the writer has succeeded or not. In this literary stylistic study, attention will focus mainly on how Eghagha stylistically manipulates diction and morphemes to foreground the themes of his collection of poems titled Rhythms of the Last Testament. A peculiar feature that permeates poetry as a genre is the use of condensed language.

\section{Review of Related Literature}

The issue of commitment in Nigerian literature in general and Nigerian poetry in particular is encapsulated in the response of Nigerian poets to the socio-political happenings in their country. Awhefeada (2006) identifies the three phases of Nigerian poetry thus: first, is the pioneer/ traditional phase which spanned from the 1930s to the early 1950s. Two prominent poets of this generation are Dennis Osadebey and Gabriel Okara. Awhefeada (2006:371) tags these poets as "the nation's crusaders, philosophers, sages and champions of African thought and freedom". The modernist generation which coincided with the attainment of Nigeria's independence in 1960 constitutes the second generation. The prominent poets of the modernist era are Wole Soyinka, J.P. Clarke and Christopher Okigbo. This generation of poets focuses the themes of their poetry on the problems of neo-colonialism, political oppression, corruption and culture conflict as the bye product of colonialism.

The new generation of Nigerian poets known as Alter/Native tradition (Note 1) are the poetic products of post civil war Nigerian society. Eghagha's poetry is situated in this generational bracket. The poets include Niyi Osundare, Odia Ofeimun, Tanure Ojaide, Onokome Okome and Hope Eghagha. These poets were disillusioned with political misrule; therefore, the themes of their poems include: the problem of political leadership, military dictatorship and endemic poverty in post civil war Nigerian society. Since these poets are committed to the social issues of their country, they have become voices of the voiceless and underprivileged Nigerians; what is more, they are also prophets of hope. Ojaide (1976:71) summarized the pre-occupation of his generation of poets thus:

Contemporary African poetry is marked by a shift from culture, nature, individualism and lyricism of the 1950s and early 1960s to the national socio-economic, political and class awareness of the 1970s and 1980s.

Apronti (1988:78), a renowned literary critic, states succinctly that commitment in African literature is germane to those of Nigerian poets thus:

The writer ... needs to be committed to a set of social, political or ethical ideas. He should be one who does things, not one to whom things are done. More than other leaders of thought in contemporary Africa, he must be in the vanguard of those who are articulating the goals of our continent or raising the level of cultural consciousness of our people.

Since the Alter/tradition generation of Nigerian poets has now spanned over three decades, it is necessary to subdivide these poets into two groups viz: the earlier and the latter. While Odia Ofeimun, Niyi Osundare and Tanure Ojaide constitute members of the earlier group, some members of the latter group include Onokome Okome, Remi Raji and Hope Eghagha. A major difference between the themes of the two groups of poets becomes apparent in the 
poems of Osundare and Eghagha respectively. Osundare's poems focused on his resentment against the tyranny of military dictatorship. Osundare's panacea to this problem of misrule is aptly described by Jones (1996:6) thus:

The strong belief that a humane democracy is the solution to his country's problems is based on an equally strong faith about the potential of the common man who ... though seemingly controllable and exploitable ... has potential for self-assertion which will be the ultimate salvation of society.

Eghagha, a leading light of the latter Alter/tradition poets, notes in his poems that democratic governance of the $4^{\text {th }}$ Republic did not engender the hope that Osundare had envisioned. So, democracy mainly breeds corrupt politicians who Eghagha (2002:iii) in his preface, calls

The vulgar clowns in robe who seize mace, aided by the mental laziness and moral gratuitousness of the mob ... our suicidal leap from the high towers is no longer news. Some words testify against them. The apes in power.

On the same page in the preface, he however, envisions a new hope for the liberation of impoverished Nigerians thus: "And so we catch the written word and wield its power even in the face of letter bombs from cowardly generals ... there will be light at the end of the tunnel."

Eghagha has earned critical notes for his poetry. A critical work by Mowarin M. (2009b) focuses on how Eghagha adroitly incorporates the technique of oral art forms in his poetry to foreground the negative effects produced by excessive post-colonial exploitation in the Niger Delta in two collections of his poetry titled Rhythms of the Last Testament (2002) and the Governor's Lodge and Other Poems (2004). Mowarin undertook a detailed analysis of how Eghagha creatively fuses elements of oral tradition - myths, proverbs, incantation, nature, imagery and legend into his poetry through a cross-fertilization of both forms of literature in order to partly recreate his naïve Urhobo oral tradition and to foreground the salient themes in the two collections. The critique observes that Eghagha creates verisimitude in his poetry by incorporating the participation of ordinary Nigerians, in their struggle for socio-economic emancipation through the use of oral art forms like refrains, chants, proverbs and incantations. He adds that Eghagha also uses orature to imaginatively recreate pre-colonial African society which was almost wiped out by slave trade and colonialism.

Eghagha's use of Nigerian pidgin as a device of rhetoric in two poems "We Satute the Generals" (39-40) in Premonition and Other Dreams and Na the same Kontri we dey" (54-55) published in Mama Dances into the Night and Other Poems received critical review from Mowarin (2009c). "While the former poem focuses on the incredible powers of serving and retired generals in Nigeria, the latter foregrounds hope for the emancipation of the oppressed in post-colonial Africa through a people's revolution. A weakness noticed in the poems in Eghagha's admixture of the acrolectal and mesolectal socialets of Nigerian pidgin which created cases of language mixing between English and Nigerian pidgin. Some undergraduate projects and masters' dissertations have also be written on Eghagha's poetry.

Hope Eghagha is a prolific poet, essayist, novelist and playwright. He is a Professor in the Department of English, University of Lagos, Akoka, Lagos State, Nigeria. Eghagha is presently the Commissioner for Higher Education in Delta State, Nigeria. His published works include Rhythms of The Last Testament (2002), This Story Must Not Be Told (2003), Emperors of Salvation (2004), Reflections on The Portrayal of Leadership in Contemporary Nigerian Literature" (2004). As a prolific eassyist, Eghagha is a visiting member of The Guardian Newspapers Editorial Board.

\section{Innovative Manipulation of Diction}

Lexical innovation is one of the prominent features of poetry. In linguistics, lexical innovation evolves from contact between phonology, lexicology and semantics. Rus, M. L. defines lexical innovation thus:

A lexical innovation can imply the use of a new lexical unit, the modification of the root or of the semantic structure of a word in a language. Emphasizing such an innovation is a process that compares different stages in the development of a language.

The contact between English and Nigerian languages has resulted in the acculturation and domestication of he English language. This has resulted in lexical innovations in African poetry. T'sou, B.K. aptly describes how language contact engenders lexical innovation thus:

When languages come into contact either directly through the personal contact of the speakers of these languages, or indirectly through the media, one common outcome is the diffusion of 
cultural items across linguistic boundaries. One clear manifestation of this cultural diffusion is the emergence of new lexical items in a recipient language. The new lexical items are replicas models in the donor language and they can be manifested in phonetic and semantic adaptations, including calques or translation loans.

Two instances of language contact induced lexical innovations that abound in African literature are translation loans and cushioned loan words.

Enkvist et al. (1969) have said that words are either in chain one thing after another and, choice one thing rather than another at the lexical level of analysis in literary stylistics. The former relation of lexical patterns is known as syntagmatic relationship while the latter, paradigmatic relationship. The syntagmatic relation is referred to as collocation while the paradigmatic relation is referred to as lexical set. Lexical set involves the tendency of a group of lexical items to share part of their collocational range with other lexical items (Osakwe, 1995). At the level of diction, this study will focus on the stylistic significance of usual and unusual collocations and lexical sets in the collection of poems.

The choice of lexical items in Eghagha's Rhythms of the Last Testament constitutes the collection's register, since the lexical items produce intellectual meaning and they illuminate how Eghagha adjusts his language to foreground the themes in the collection of poems. A careful study of the lexical sets that pervade Rhythms of The Last Testament reveals the themes and geographical setting of the collection of poems. The nodes that dominate the lexical paradigms are the environmental and socio-political situation in the Niger Delta in particular and Nigeria in general. The environmental issue is dominated by environmental degradation as the denominator. The problems of environmental degradation highlighted in the collection of poems can be diagrammatically illustrated with a schema as shown in Figure I below.

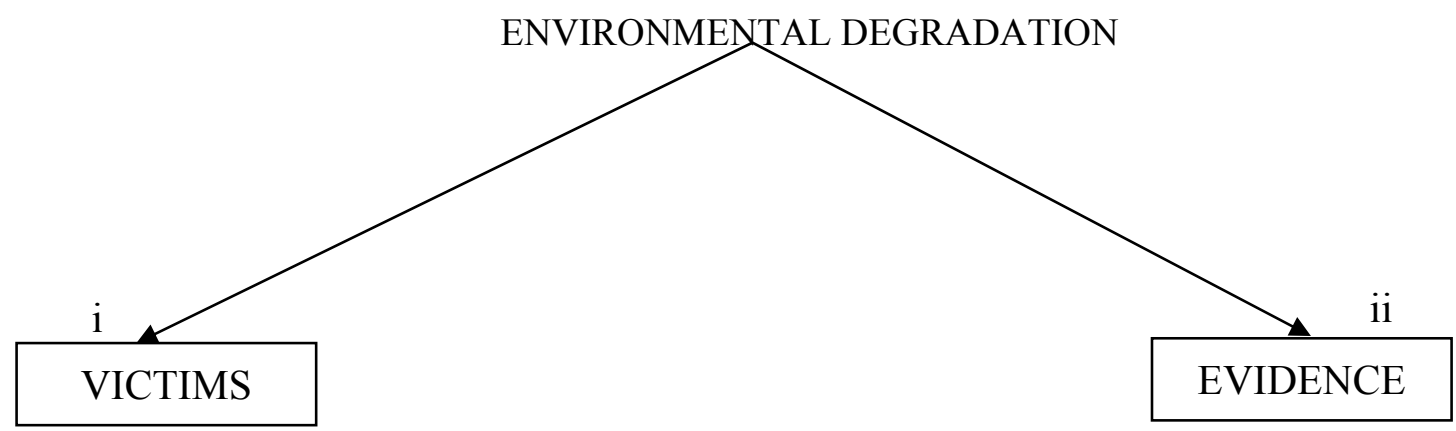

Fresh Lunatic (8)

The nine men (13)

(The Executed Ogoni nine)

Open-eyed refugees (45)

Fish-belly bobbling (34)

Womb of death (12)

Flames of hunger (31)

Wawi's Legacy (19)
Spilled black gold (31)

Flames the land (31)

Black water (3)

Petrol on fire (31)

Green floods (9)

Oil fire of Jesse (9)

Black like Jesse's smoke (9)

Burnt insides (9)

Figure 1. Lexical Sets in paradigmatic relations that Underscore

Theme of Environmental Degradation in the Niger Delta Region

Figure 1 above depicts lexical items in paradigmatic relations that foreground the theme of environmental degradation in the Niger Delta region and its effect on its inhabitants. The main victims are aquatic life in the numerous rivers and creeks of the region. Four poems that vividly describe the victims and the impact of environmental degradation of the Niger Delta are: "Black Gold" (34), "The Last Lover" (9), "The Divorce" (31) and "In The Dock" (13). 
"Black Gold" begins with a vivid description of environmental friendly Niger Delta region before the advent of oil exploitation thus:

I remember the green leaves

The pods, the rubbers

We ate the fatlings

From moon to moon

The earth danced to its music

The fishes

Needed no nets' to grace our pots (34).

Oil exploitation brought about a dramatic change to the erstwhile environmental friendly region. With oil exploitation, the rivers and creeks became polluted; fishes and other aquatic creatures met their untimely death. Eghagha gives an apt description of loss of aquatic life thus:

Now

Fish come belly - bobbling

Deep cuts on your faces

A testimony of burnt insides. (34)

Loss of aquatic life also connotes the displacement of people from their natural habitats once their rivers are polluted. Since they can neither fish, bath, cook nor wash with the polluted water, the logical option for the inhabitants is to relocate from their natural habitat to a new and strange one. A phrase that foregrounds the victims of environmental degradation is "The nine men" (13) in the poem titled "In the dock" (13). It describes the trial of the Ogoni nine and their eventual execution on Friday No. 9, 1995. This date is now tagged "The Black Friday". For daring to draw world attention to the devastating effect of environmental pollution in the Niger Delta, Ken Saro Wiwa and other eight prominent Ogoni activists paid the supreme price with their lives.

In Eghagha's Rhythms of The Last Testament, there are many lexical items in paradigmatic relation, especially in the four poems mentioned above, which give vivid evidence of environmental pollution. Some of them include "Spilled black gold" (31) and "black water" (31).

The following lexical items in paradigmatic relations "petrol on fire" (31) and "fire of Jesse" (9) vividly serve as reminders of fire incidents that emanated from burst oil pipelines. Thousands of lives have been lost due to impoverished indigenes of the regions trying to scoop petroleum products from burst oil pipelines. From the analysis above, Eghagha foregrounds the theme of environmental degradation by projecting two lexical items in paradigmatic relations in figure 1 titled:

i) The victims of environmental degradation.

ii) Evidence of environmental despoliation.

Apart from the fact that lexical cohesion is achieved in the text through the lexical relations of the lexical sets that foreground the theme of environmental degradation above, Rhythms of the Last Testament achieves its texture as a piece of discourse through these lexical sets since they spread throughout the collection of poems.

The socio-political situation in Nigeria will be analyzed by the lexical sets grouped into A, B and C on the schema titled figure 2. 
A Impoverished and oppressed Nigerians

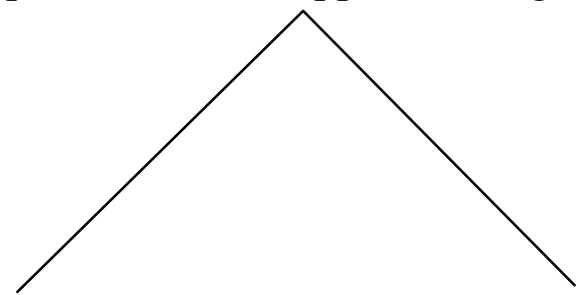

(i) POVERTY \& DISEASE

Tathered Souls (31)

Famished flesh (31)

Eyes of dementia (30)

Dark riverside (13) (ii) POLITICAL TYRANNY

The nine men (3)

The victims (15)

Open-eyed refuges (45)

Letter of blood (14)

Kill the corpse (31)

Gun totters (50)

Masked men (50)

Marks men (50)

Tear the skin (5)

Sand-bars (17)
B

Corrupt and avaricious rulers

Sprawling bustard (35)

Hundreds of rooms (35)

Suits in capitals (35)

Flowing apparel men (8)

Wicked kangaroo (13)

Rapacious one (23)

Stashing black money (35)

Golden vaults (31)

Abuja Sheraton (35)
Wash anew (17)

Still comfort of

Six by two (25)
Hope 
The two lexical paradigms in C foreground the theme of hope. With the lexical sets, Eghagha portrays himself as neither a pessimist nor merely a chronicler of the effects of environmental degradation and political misrule on Nigerians but as a committed poet with a vision for social change. The lexical set "wash anew" (17) is taken from the poem "Sand-bars" (17). "Sand-bars" symbolize the tyrannical and avaricious rulers who will eventually be washed away by a wind of change as Eghagha shows below:

Sand-bars blocks us

From our dreams

Sand-bars

Sand-bars?

We need them no more

Let the floods come wash anew (17)

As a clairvoyant poet, Eghagha foresees the death of the tyrannical leaders with the lexical set "comfort of a six-by two" (25), which symbolizes their graves. In the poem "At the bar's back" (35), Eghagha aptly describes their demise thus:

Once Lords of sprawling hectares

Hundreds of rooms

Suits in capitals

Now embrace stiff

Comfort of a six-by two

How art thou fallen? ("At the bar's back" p. 35)

Eghagha is optimistic that with the passing of time, the ordinary Nigerians suffering under tyranny will find comfort and relief once the dead tyrants are replaced by benevolent democrats who will transform Nigeria into an egalitarian society. Eghagha (2002:iii) aptly describes this in his preface thus:

And so we catch the written word and wield its power even in the face of letter bombs from Cowardly Generals ... there will be light at the end of the tunnel

So, figure 2 foregrounds the themes of avaricious and tyrannical political leaders on the one hand, and that of hope for the emancipation of impoverished Nigerians on the other hand. The three lexical paradigms that foreground these two themes as shown in figure 2 above, are

i) Impoverished and oppressed Nigerians

ii) The avaricious and tyrannical political leaders

iii) Hope

Textual cohesion is achieved in Rhythms of The Last Testament through the preponderance of the paradigmatic relationships in Figure 2 in the poems as shown in the analysis above.

\section{Collocational Shift}

Collocation is an important concept in the stylistic analysis of poetry at the level of lexis because the poet often achieves some of his messages and foregrounds his meaning and themes through the interaction between usual and unusual collocations (Osakwe, 1995). Apart from the lexical sets discussed earlier, Eghagha's use of condensed language is also evidenced in his use of collocational shifts, metaphors and mixed metaphors. Three examples of unusual collocations are stated below.

First, is the unusual collocation between procession and stagnancy found in the poem "The Call of Akpobrisi" (p. 57) where Eghagha states: "Unveil the masquerade which holds the procession in Stagnancy"

A second collocational shift is "old new year" in the sentence below in the poem "Old New Year" (p. 43)

"The people re-enter old boat paddle from the old into the 'old new year'.

Thirdly is the unusual collocation between backward and gliding in "Backward gliding' (“Old New Year", p. 43). 
The three unusual collocations: "procession in stagnancy", "backward gliding" and "old new year" foreground the adverse effect of misrule on the nation and her people. The nation had not only remained socio-economically stagnant but it has also retrogressed since independence in 1960.. This is in contradistinction with the Asian Tigers like Malaysia, Taiwan and South Korea which have been transformed technologically within the same period.

In "procession in stagnancy", procession shares two range of collocations which are first, the usual collocation of procession with a movement towards a new destination and second, the unusual collocation procession with stagnancy which depicts absence of movement and by implication absence of a new destination. The unusual collocation "backward gliding" connotes a retrogressive movement. This is why:

"The people re-enter the old boat paddle from the old into the old" (43).

The last unusual collocation, "old new year", aptly captures the people's retrogression socio-politically and economically. Old/New cannot share the same collocational range with year; however, due to the abject poverty of common Nigerians, the growing number of slums in urban centres and the environmental degradation of the Niger Delta Region, the nation, as well as its citizens, annually enter into an "old new year" (43).

An overt example of metaphorical language in Eghagha's collection of poems is in the poem titled "Wawi's Legacy" (p. 19). The poem identifies the legacy of the late human rights and environmental activist, Ken Saro Wiwa. Part of the poem reads:

You must sharpen your axe to hack off Wawi's head

I. Wawi's head is made by steel,

You must sharpen your spears to pierce his heart.

II. His heart is insulated.

You must crack the skull with the butt of guns

III. But his brain is on paper

You must burn his soul

IV. His spirit is the people (Wawi's legacy, p. 19). (Numbering and italic are mine)

The four metaphors identified in the poem are definitional since they involve transference through the use of "BE" verb. The last metaphor "his spirit is the people" is a mixed metaphor since it is both definitional and concretive, because a physical attribute is ascribed to "spirit" which is an abstract object. The four metaphors in this poem foreground Eghagha's hope for the emancipation of his people from the clutches of tyrannical leaders. Rather than obliterate Ken Saro Wiwa, the tyrannical leader who ordered his execution paradoxically immortalized him. So Eghagha opines in this poem that the execution, incarceration and torture of so called dissidents by the tyrannical rulers cannot truncate the eventual emergence of a new dawn in the nation.

\section{Lexical Items that Foreground Rhythms of the Last Testament Geographically}

Certain lexical items used by Eghagha in his collection of poems help to identify their geographical setting. These lexical items are derived from Eghagha's geographical background. Eghagha, an Okpe indigene, was born and bred in the Warri/Sapele speech community of Delta State in the Niger Delta region of Nigeria. The major ethnic nationality in this speech community is Urhobo. Urhobo, Okpe and Uvwie (Effurun/Erhron) are the three languages that constitute that ethnic nationality and they are members of the South Western Edoid languages Elugbe (1986:16) observes the linguistic relationship between the three languages thus:

Although the Okpe and Uvwie will call themselves part of the Urhobo ethnic nationality and speak the central Agbarho dialect of Urhobo which has become a lingua franca in the Urhobo area, they rightly insist that they have their own languages.

The lexical items can be grouped into two viz:

A. Name of Places - i - iv

B. Foreign words (cushioned loan words) $\mathrm{i}$ - iii. They are mainly Urhobo words.

\section{A. Names of Places}

i. Warri - The commercial nerve centre of Delta State where oil companies in the State are located. It is also known as "oil city." 
ii. Sapele - The administrative headquarter of Sapele Local Government Area in Okpe Kingdom of Delta State in Nigeria.

iii. Jesse - A rural community close to Sapele where the first oil pipeline fire disaster occurred in 1998. Over 3,000 people died in the inferno.

iv. Mereje - A rural community located between Sapele and Warri.

\section{B. Cushioned Loan Words}

i. Aridon - God of memory in Urhobo mythology

ii. Akpobrisi - A powerful tree inhabited by spirits in Urhobo mythology

iii. Ewgheya - A group of old women who can invoke a curse on either a community or an individual while they are naked.

The examples above which place the poem geographically are the effects of socio-cultural influence of Eghagha's society on Rhythms of The Last Testament.

\section{Morphological Innovation}

This section of the paper discusses how Eghagha causes major morphological rupture in order to stylistically foreground meaning in Rhythms of The Last Testament. Morphology is essentially studied under the purview of linguistics; however, the linguistic appraisal of the poems is meant to complement the literacy interpretation of the collection. Aronoff M. and Fudeman, K undertake an etymological overview of the term morphology thus:

The term morphology is generally attributed to the German poet, novelist, playwright, and philosopher Johann Wolfgang von Goethe (1749-1832), who coined it early in the nineteenth century in a biological context. Its etymology is Greek: morph- means "shape, form', and morphology is the study of form or forms. In biology morphology refers to the study of the form and structure of organisms, and in geology it refers to the study of the configuration and evolution of land forms. In linguistics morphology refers to the mental system involved in word formation or to the branch of linguistics that deals with words, their internal structure and how they are formed.

Spencer A. and Zwicky A.(2001:1) note the indispensible feature of morphology with regards to interface in linguistics thus:

Morphology is at the conceptual centre of linguistics ... because it is the study of word structure and words are at the interface between phonology, syntax and semantics.

As a gifted wordsmith, Eghagha evolved many morphological innovations in the collection. This is attributable to his training in English. Four of such morphological dislocations are discussed below:

First, is "yester-lustre" in

Now your eyes

Are a shadow

of "yester-lustre" (Echoes of a Lover's quest, p. 18).

A bound morpheme, "yester-", is extrapolated from yesterday and yoked together with a free morpheme, "Lustre" by a hyphen-. This derived word has the attribute of a hyphenated compound word. The word derived through this morphological disruption is meaningless if it occurs alone but when it is placed contextually in the poem, its illumination stares the reader on the face. Although, lustre is a polysemous word, in the context in which it is used, however, it means shineness and spriteness. While "yester" denotes the past, lustre illuminate the shineness' and brightness of the love, that existed in the past. Presently that brightness and ornamental shineness are now part of the past. Another morphological dislocation is "deathly" in

Ocean coloured savior

Tied "deathly" together

By the tautness of your love

(The River of my Ocean, p. 26). 
Although we will focus on the morphological innovation that led to the derivation of the adverb "deathly", attention will also be focused on collocation of "deathly together". Death is derived through nominalization of the adjective $\mathrm{dead}$. Nominalization is the only derivational morphological process which operates on English adjectives. Eghagha engages in morphological innovation by deriving the adverb "deathly" from nominalized adjective "death" through the by suffixation of the adverbial bound morpheme-ly. This is not an acceptable derivational morphological process in English. what is acceptable, as a word formation process in English, is the derivation of adverb "deathly" from the adjective'dead'.. But deathly in this context does not denote a bond that can only be separated by death in "deathly together."

So, "deathly" can aptly be described as neologism. The focus of the poet is the bond of love between the lovers which is inseparable until death do they part. So, there exists a love bond tied "deathly together". This economic use of word is an attribute of a consummate wordsmith.

The next morphological innovation by Eghagha in his collection of poems is

"sharking" in

We shall be dolphins

Play at water

When the sharks

Come sharking

In our ocean (“The River of my Ocean", p. 25).

The suffix-ing is an inflectional one which derives continuous tense from a verb in the present tense. An example is take - taking. In the context in which "sharking" is used, Eghagha innovatively derives a causative verb from the noun "shark" by changing an inflectional suffix to a derivational one. So, the verbal "sharking" is derived from the noun shark. The imagery of shark as the most ferocious carnivore in the ocean is spine shilling. So, when the sharks come "sharking", the concomitant is death and injury to creatures in the ocean. The sharking sharks are the tyrants that wreck havoc on their citizens. The citizens are symbolized by "dolphins". Dolphins are compassionate, gracious and jaunty creatures of the ocean. What Eghagha did is to juxtapose the two opposing forces in the society by foregrounding the functions of sharks as ferocious hunters of the deep sea.

Another morphological innovation used by Eghagha is the swapping of the two morphemes in a disyllabic noun followed by genitivization of the proper noun. The proper noun that Eghagha morphological dislocated is Wiwa in "Wawi's Legacy" (19). The genivization of Wiwa to Wawi's and Eghagha's change of its word class from a proper noun to a common noun through the use of small letter in the first phoneme ' $W$ ' to " $w$ " are stylistically used by Eghagha to foreground the theme of hope. It also immortalizes Ken Saro Wiwa. Although Ken Saro Wiwa is physically dead, his soul and spirit have transcended from mortality to immortality; therefore, Wiwa's creative works, his valour, soul and spirit are immortalized through Eghagha's morphological innovation.

\section{Conclusion}

The role of the poet in a developing society like Nigeria is quite pitiable because his poetry antagonizes the avaricious and despotic tendencies of the rulers. Eghagha's poetry is at the vanguard of this antagonism because the issue of commitment still occupies the front burner of his collection of poems. The uniqueness of Eghagha;s poetry is in his dexterous manipulation of lexical sets, collocational overlaps and morphological innovations to highlight the distortions in the society due to political misrule. These lexical innovations foreground the extent to which Eghagha has domesticated and colonized the English language to capture the labyrinths of the Niger Delta region.

Apart from testifying against the repugnant problems of environmental degradation, the rapacity and callousness of the tyrannical rulers, part of Eghagha's diction also heals the broken soul of the oppressed. Eghagha's creative manipulation of English diction and morphology foregrounds the interface between language and literary creativity in the use of the English Language.

\section{References}

Apronti, E.O. (1988). The Writer in our Society, In Y. Ogunbiyi (Ed) Literature and Modern West African Culture" 1700 to the Present, Vol. 2. (pp 36-52) Lagos, Guardian Books.

Aronoff, M. \& Fudeman,k. (2013). "What is Morphology?" Retrieved June 20, 2013. [Online] Available: www.ucd.ie/ortspgs/introling/Aronoff morphology.pdf 
Awhefeada, S. (2006). Poetry and National Evolution: The Nigerian Experience, in S. Ukala (Ed) African Arts and National Arts and National Development. (pp 367-384) Ibadan Kraft Books Limited.

Ayeomoni, M. (2009). "Language and Deterministic Ideology in William Blake's Poetry: A case study of "Columbus" in M. Mowarin (ed). Abraka Humanities Review. 2(2) .(pp 1-13)

Banjo, A. (1982). "The Linguistic factor in African Literature: A Keynote Address" (A paper presented at the University of Ibadan, Ibadan.

Eghagha, H. (2002). Rhythms of the Last Testament. Lagos: Concept Publications.

Elugbe, B. (1986). Comparative Edo Phonology and Lexicon. Port-Harcourt: Port-Harcourt University Press.

Enkvist, N. E. et al. (1969). Linguistics and Styles. London. Oxford University Press.

Freeman, D. (1983). "Modern Stylistics" In I.R. Failey (Ed) Syntactic Deviation and Cohesion R. Failey New - York. Methuen \& Co.

Halliday, M.A.K. (1973a). Exploration in the Functions of Language. London Arnold.

Jones, E. D. (1996). "Editorial” African Literature Today, No. 20.

Mowarin, M. (2009b). "The Language of orature in Hope Eghagha's Poetry" East-West Cultural Passage (Journal of the Peter Magrath Research Centre for Cross Cultural Studies) No. 8 sibiu 107-136.

Munene, M. (2006). "Politics and the African Intellectuals: Perspective from East Arica." In G. Adeoti and R. Evwierhoma (Eds) After the Nobel Prize: Reflections on Afrian Literature: Governnance and Development (pp 187-205) Lagos Kraft Books.

Nazareth, P. (1965). "The African Writer and Commitment". Transition, Vol. 19. 45-60.

Ojaide, T. (1996). Poetic Imagination in Black Africa. Durbam: North Carolina University Press.

Osakwe, M. (1985). A Linguistic Guide to Soyinka's Idanre and other poems. Ibadan: Ibadan University Press.

Rus, M.L. (2013). "Lexical Innovation" Retrived, $26^{\text {th }}$ June, 2013 from Cis01.Central.ucv.rollitere/onomastico---Irevista/.../maria-laura_rus pdf

Spencer, A. \& Zwicky, A. (2001). "Introduction” The Handbook of Morphology. Oxford: Blackwell Publisher Ltd. http://dx.doi.org/10.1111/b.9780631226949.2001.x

T'sou, B.k. (2013). Language Contact and lexical innovation. Retrived $26^{\text {th }}$ June, 2013. from wwwWsc.uni-erlangey.de/pdf/tsou.pdf.

Udenta, O. U. (1996). Art Ideology and Social Commitment in African Poetry: A Discourse. Enugu: Fourth Dimension Publishers.

Wales, K. (1990). A Dictionary of Stylistics. Essex: Longman Group.

\section{Notes}

Note 1. For a detailed analysis of the concepts "Alter-Native Tradition" See Aiyegina, Funso "Recent Nigerian Poetry in English: An Alter-native Tradition" Ogunbiyi, Yemi (ed) Perspectives on Nigerian Literature, Vol. one, 17000 to the present. Lagos, Guardian Books Nigeria Ltd. $112-118$.

Note 2. A detailed discussion of Edoid languages can be found in Elugbe, B. (1986) Comparative Edo Phonology and lexicon. Port-Harcourt: University of Port-Harcourt Press. 